\title{
Colour and Quality of Strawberry Fruit (Fragaria $x$ ananassa Duch.) at Different Levels of Maturity
}

\author{
Ni Made Defy Janurianti *, I Made Supartha Utama , Ida Bagus Wayan Gunam \\ Master Program of Food Technology, Faculty of Agricultural Technology, Udayana University \\ * defyjanurianti@gmail.com
}

\begin{abstract}
Strawberry fruit has five levels of maturity in terms of the color of the strawberry fruit. One of the important factors that affect the fruit's resistance from mechanical damage is the level of fruit maturity. At different levels of ripeness, strawberries have different nutritional content. The strawberries used are obtained from strawberry farmers in Pancasari Village, Tabanan Regency. The level of fruit maturity analyzed was divided into five stages, namely 0, 25\%, 50\%, 75\%, and 100\% of the red fruit. Based on the ANOVA variety results, the parameters of color, texture, $\mathrm{pH}$, total acid content, total acid content, vitamin $C$ content, and anthocyanin levels of strawberries at different levels of maturity showed very significant differences $(P<0.01)$. Strawberry fruit at the optimal level of maturity obtained the value of $L *$, namely 18.45, a*, namely 67.04, $b *$ namely 20.86, texture of $7.46 \mathrm{~N}$, pH of 3.36, total acid of 2.09 (meq $\mathrm{NaOH} / \mathrm{g}$ ), total dissolved solids was $6.40^{\circ} \mathrm{Brix}$, vitamin C levels were $66.24 \mathrm{mg} / 100 \mathrm{~g}$, and anthocyanin levels were 329.07 ( $\mathrm{mg}$ PGN / $100 \mathrm{~g}$ ).

Keywords: Strawberries, Maturity Level, Colour, Quality
\end{abstract}

\section{Introduction}

Strawberries are a type of fruit that has high economic value. In Indonesia, there have been many strawberry fruit cultivation, especially in highland areas. Strawberry fruit has a characteristic: the main stem is short and has compound leaves with three leaflets (trifoliate) with serrated leaf edges. Leaves formed in each book. In the axillary leaves, there are shoots. The strawberry plant looks like a clump without stems [1].

Strawberry fruit has a red color because it is rich in anthocyanins. Strawberry fruit has health benefits because of its diverse nutritional content, namely flavonoids, phenolic acids, and tannins (proanthocyanidins). Strawberries are also rich in vitamin C (about $60 \mathrm{mg} / 100 \mathrm{~g}$ fresh fruit), folate (about $24 \mathrm{~g} / 100 \mathrm{~g}$ fresh fruit), and minerals (manganese, potassium, magnesium, copper, iodine, phosphorus, and iron) [2]. The main organic acid content found in strawberries is citric acid. The organic acid content in strawberries will increase as the fruit ripens [3]. Strawberry fruit has been tested both in vitro and in vivo and has been known to have antioxidant, cardioprotective, anticancer, anti-inflammatory, antidiabetic, antimetabolic syndrome, antiobesity, neuroprotection, and antimicrobial properties [4].

Strawberry plant growth is speedy and reaches a maximum of approximately 30 days after anthesis, which depends on environmental conditions. The strawberry growth curve is in the form of a sigmoid curve [5]. Strawberries are non-climatic fruit that has a short harvest period and should be harvested when the fruit is fully ripe. The ripeness of strawberries is divided into five stages; namely, the first stage begins with white fruit, the second stage, $25 \%$ of the fruit is red, the third stage is $50 \%$ of the fruit is red. In the fourth stage, $75 \%$ of the fruit is red, and in the fifth stage is $100 \%$ of the fruit has been red [6]. One of the crucial factors that affect the fruit's resistance from mechanical damage is the level of fruit maturity. At different levels of ripeness, strawberries have different nutritional content. 


\section{Material and Methods}

\subsection{Material}

The strawberries (Fragaria $x$ ananassa Duch.) Obtained use from strawberry farmers in Pancasari Village, Tabanan Regency. Strawberries sort according to the criteria, namely fruit weight $12-15 \mathrm{~g}$. The level of fruit maturity analyzed was divided into five stages, namely $0,25 \%, 50 \%, 75 \%$, and $100 \%$ of the red fruit.

\subsection{Quality Assessment}

\section{Colour}

Fruit color was measured using the Colorimeter parameter (Cs-280, Zhejiang) as L *, a *, b * (CIELab) values [7]. The color readings were carried out three times in each fruit's equatorial area and averaged to give each fruit a value.

\section{Texture}

The texture of the strawberry fruit was analyzed using the Texture Profile Analysis (TPA) method using the TA.XTplus texture analyzer [8].

\section{pH}

The $\mathrm{pH}$ measurement method is based on the potentiometric/electrometric measurement of the hydrogen ion activity using a $\mathrm{pH}$ meter [8].

\section{Total Dissolved Solids}

Total dissolved solids were measured using a hand refractometer [8]. The refractometer number shows the total dissolved solids ( ${ }^{\circ}$ Brix) level.

\section{Total Acid}

Total Acid calculates by the titration method [8]. The total acid test was carried out by placing a $10 \mathrm{ml}$ sample into a $100 \mathrm{ml}$ volumetric flask, adding distilled water to the boundary mark then homogenizing and filtering. $25 \mathrm{~mL}$ of the filtrate was taken and put into the Erlenmeyer. Added PP 2 - 3 drops indicator. Titrated with $0.1 \mathrm{~N} \mathrm{NaOH}$ solution to form a pink color.

\section{Vitamin C}

Prepared the reagent solution by mixing $500 \mathrm{ml}$ of $0.6 \mathrm{M}$ sulfuric acid with $5.322 \mathrm{~g}$ sodium phosphate and $2.471 \mathrm{~g}$ ammonium molybdate. The reagent $(3 \mathrm{ml})$ was mixed with $0.3 \mathrm{ml}$ of sample and incubated at $95^{\circ} \mathrm{C}$ for 90 minutes in a water bath. After incubation, it was cooled in water for 5 minutes before absorbance measure at $695 \mathrm{~nm}$. Results expressed as the ascorbic acid equivalent in $\mathrm{mg} / \mathrm{g}$. Vitamin $\mathrm{C}$ levels calculate with the following formula, where $\mathrm{C}$ is the sample concentration from the linear regression results $(\mathrm{mg} / \mathrm{L}), \mathrm{V}$ is the volume of the pipette sample $(\mathrm{L})$, Fp is the dilution factor, $\mathrm{W}$ is the sample weight $(\mathrm{g})$ [9].

$$
\text { Total Vitamin C }(m g A A E / g \text { extract })=\frac{\mathrm{CxVxFp}}{\mathrm{W}}
$$

\section{Anthocyanin Levels}

The sample is 2 grams added with $0.5 \% \mathrm{HCl}$ in methanol as much as $18 \mathrm{~mL}$ and kept for 1 hour to extract the pigment. The solution is filtered, and the filtrate analysis at an absorbance of $520 \mathrm{~nm}$. Total anthocyanin calculates using the following formula: A520 $\times$ dilution factor $\times$ [molecular weight (MW) of PGN / Molar extinction coefficient] where MW of PGN $=433.2$ and Molar extinction coefficient $=2.908 \times 104$. The result is articulated as mg of pelargonidin equivalent (PE) $100 \mathrm{~g}-1 \mathrm{of}$ fresh fruit mass [10]. 


\section{Light microscopy}

Strawberries at different ripeness levels are thinly sliced using a razor blade and attached with a drop of distilled water. The slides were examined in a bright field using a light microscope (Leica, Germany) equipped with a digital camera.

\subsection{Data analysis}

This study used a simple complete randomized design. The data obtained were analyzed by using the ANOVA variance fingerprint using SPSS version 24. The results of the variance fingerprint showed a significant $(\mathrm{P}<0.05)$ to very real $(\mathrm{P}<0.01)$ effect of the treatment, then continued with Duncan's multiple distance test. 11].

\section{Results and Discussion}

Based on the ANOVA analysis of variance, it showed that strawberries at different ripeness levels had very significant color values ( $\mathrm{L} *, \mathrm{a} *, \mathrm{~b} *)$, texture, $\mathrm{pH}$, total acid content, vitamin $\mathrm{C}$ levels, and anthocyanin levels $(\mathrm{p}<0,01)$.

Table 1

Fruit surface (Microscopy) and color ( $\mathrm{L}^{*}, \mathrm{a} *, \mathrm{~b} *$ ), texture, $\mathrm{pH}$, total acid content, vitamin $\mathrm{C}$ content, and anthocyanin levels in Strawberry Fruit

\begin{tabular}{|c|c|c|c|c|c|}
\hline No. & Fruit Stage & $\begin{array}{l}\text { Fruit Surface } \\
\text { (Microscopy) }\end{array}$ & $\begin{array}{l}\text { Colour } \\
\mathrm{L} *\end{array}$ & $\mathrm{a} *$ & $\mathrm{~b} *$ \\
\hline 1 & Stage 1 & & $57.63 \pm 0.790 \mathrm{a}$ & $-10.65 \pm 0.397 \mathrm{~d}$ & $35.80 \pm 1,880 \mathrm{a}$ \\
\hline 2 & Stage 2 & & $47.40 \pm 4,175 b$ & $7.56 \pm 5,280 \mathrm{c}$ & $33.57 \pm 2,972 \mathrm{a}$ \\
\hline 3 & Stage 3 & & $38.09 \pm 4.032 \mathrm{c}$ & $21.58 \pm 10,672 b$ & $39.95 \pm 6,743 \mathrm{a}$ \\
\hline 4 & Stage 4 & & $20.28 \pm 0.895 \mathrm{~d}$ & $64.83 \pm 1.251 \mathrm{a}$ & $15.45 \pm 3.454 \mathrm{~b}$ \\
\hline 5 & Stage 5 & & $18.45 \pm 0.915 \mathrm{~d}$ & $67.04 \pm 2,920 \mathrm{a}$ & $20.86 \pm 2.875 b$ \\
\hline
\end{tabular}

\section{Colour}

During the ripening process of the Strawberry fruit, the color of the fruit develops from white to red. The development stage divides into five stages. Identify the color of the strawberry using the coordinates $\mathrm{L}^{*}, \mathrm{a} *$, and $\mathrm{b} *$ (Table 1 ). The $\mathrm{L} *$ value shows the light/light of a material, the * value is the red/green coordinate, and the $\mathrm{b} *$ value is the yellow/blue coordinate. Based on the $\mathrm{L} *$ value, the riper the strawberries, the brightness value decreases. This indicates that the ripe the fruit is, the darker it will be. The * value in strawberries increases with the strawberries' ripening. The redder the fruit eats, the * value, an increase in anthocyanin levels that causes a red color in the strawberries. 
The value of $b *$ decreased during the fruit ripening process. The fruit that has not been installed tends to be yellowish-white so that the $\mathrm{b} *$ value is high, and during the ripening process, the fruit turns red, which causes the $\mathrm{b} *$ value to decrease. The color change is an indicator of a very significant change in the ripening process of the fruit. Color change in fruit is a process of synthesizing pigments in fruit, such as carotenoids, anthocyanins, flavonoids, and chlorophyll overhaul [12]. The bright red color of the strawberry (Fragaria virginiana) comes from its anthocyanin content [13].

Table 2

Texture, $\mathrm{pH}$, the total dissolved solids content in Strawberries

\begin{tabular}{lllll}
\hline No. & Fruit Stage & Texture $(\mathrm{N})$ & $\mathrm{pH}$ & TSS $\left({ }^{\circ}\right.$ Brix $)$ \\
\hline 1 & Stage 1 & $39.08 \pm 8,755 \mathrm{a}$ & $3.01 \pm 0.024 \mathrm{c}$ & $4.30 \pm 0.000 \mathrm{e}$ \\
2 & Stage 2 & $18.17 \pm 0.207 \mathrm{~b}$ & $3.08 \pm 0.049 \mathrm{c}$ & $5.10 \pm 0.100 \mathrm{~d}$ \\
3 & Stage 3 & $14.31 \pm 0.996 \mathrm{bc}$ & $3.25 \pm 0.092 \mathrm{~b}$ & $5.30 \pm 0.000 \mathrm{c}$ \\
4 & Stage 4 & $11.28 \pm 1,819 \mathrm{bc}$ & $3.32 \pm 0.049 \mathrm{ab}$ & $6.25 \pm 0.050 \mathrm{~b}$ \\
5 & Stage 5 & $7.46 \pm 1.004 \mathrm{c}$ & $3.36 \pm 0.017 \mathrm{a}$ & $6.40 \pm 0.000 \mathrm{a}$ \\
\hline
\end{tabular}

\section{Texture}

Table 2 shows the texture of the strawberry fruit decreasing during fruit ripening. The unripe fruit has a hard texture and softens during the ripening process. Fruit texture influence by pectin content. Pectin is a naturally occurring complex carbohydrate found in all plants' cell walls, regulating water flow between cells and providing rigidity to cells [14]. Fruit softening is caused by damage to cell structure, cell wall composition, and intracellular material. It is a biochemical process involving the hydrolysis of pectin and starch by enzymes such as wall hydrolases. As the fruit ripening process progresses,

\section{Total Dissolved Solids}

The total dissolved solids of the strawberries increased during the ripening process (Table 2). When fruit is ripening, the dissolved solids will increase [16]. This increase is sharper when there is very fast transpiration. In the fruit ripening process, the fruit's starch degrades and is converted into dissolved sugar components by the enzymes $\alpha$-amylase and $\beta$-amylase [17]. As the fruit ripens, the total sugar level increases with decreasing invertase enzyme activity [18].

\section{pH}

The $\mathrm{pH}$ value of strawberries increases during the ripening process (Table 2). From the study results, the $\mathrm{pH}$ value in the 1st stage of breaking was not significantly different from the 2 nd stage with $\mathrm{pH}$ values of 3.01 and 3.08, respectively, but was significantly different at the next maturation stage. The $\mathrm{pH}$ value increases with decreasing total acid levels in strawberries.

Table 3

Fruit surface (Microscopy) and color $\left(\mathrm{L}^{*}, \mathrm{a} *, \mathrm{~b} *\right)$, texture, $\mathrm{pH}$, total acid levels, vitamin $\mathrm{C}$ levels, and anthocyanin levels in Strawberries

\begin{tabular}{llrll}
\hline No. & Fruit Stage & $\begin{array}{l}\text { Total Acid }(\mathrm{meq} \\
\mathrm{NaOH} / \mathrm{g})\end{array}$ & $\begin{array}{l}\text { Vit. C }(\mathrm{mg} / \\
100 \mathrm{~g})\end{array}$ & $\begin{array}{l}\text { Anthocyanins }(\mathrm{mg} \text { PGN } \\
/ 100 \mathrm{~g})\end{array}$ \\
\hline 1 & Stage 1 & $5.62 \pm 0.384 \mathrm{a}$ & $34.95 \pm 0.072 \mathrm{~d}$ & $31.06 \pm 2,309 \mathrm{e}$ \\
2 & Stage 2 & $3.26 \pm 0.072 \mathrm{~b}$ & $42.50 \pm 0.072 \mathrm{c}$ & $71.13 \pm 0.074 \mathrm{~d}$ \\
3 & Stage 3 & $2.34 \pm 0.087 \mathrm{c}$ & $49.98 \pm 0.502 \mathrm{~b}$ & $89.75 \pm 0.223 \mathrm{c}$ \\
4 & Stage 4 & $2.19 \pm 0.088 \mathrm{c}$ & $50.33 \pm 0.707 \mathrm{~b}$ & $252.20 \pm 2,086 \mathrm{~b}$ \\
5 & Stage 5 & $2.09 \pm 0.088 \mathrm{c}$ & $66.24 \pm 1,804 \mathrm{a}$ & $329.07 \pm 0.447 \mathrm{a}$ \\
\hline
\end{tabular}


During the fruit's ripening process, the fruit's organic acids are broken down into sugar after the respiration process takes place. Organic acids, such as malic or citric acid, are the primary substrates for respiration [19]. Increasing the $\mathrm{pH}$ value indicates that the fruit's organic acid value decreases because the total sugar in the fruit increases [20].

\section{Total Acid}

The highest levels of total acid for strawberries were obtained in fruit with stage 1 ripening and decreased with fruit ripening (Table 3). The decrease in the total acid level causes the $\mathrm{pH}$ of the fruit to increase. This is because the organic acids, after the respiration process, will turn into sugar. A decreased value of organic fruit acids indicates that fruit metabolism is going well [21].

\section{Vitamin C}

Table 3 shows that the vitamin $\mathrm{C}$ levels of strawberries increase during the fruit ripening process. Fruits with a 100\% maturity level have the highest vitamin C levels, namely $66 \mathrm{mg} / 100 \mathrm{~g}$. The increase in vitamin $\mathrm{C}$ levels occurs because of the synthesis of Ascorbic acid from fruit glucose during the ripening process. During fruit ripening, the amylase enzyme converts starch to maltose, and the maltase enzyme converts maltose into glucose. Furthermore, glucose, fructose, sucrose, and $\mathrm{D}$-galactose in tissues convert to ascorbic acid or vitamin $\mathrm{C}$ [22]. The maximum level of vitamin $\mathrm{C}$ occurs when the fruit is ripe, indicated by a change in color, indicating that vitamin C's biosynthesis is at its optimum [23].

\section{Anthocyanins}

Strawberry anthocyanin levels increased during fruit ripening (Table 3). The bright red color of the strawberry (Fragaria virginiana) comes from its anthocyanin content [13]. During the ripening process, anthocyanin pigments synthesize so that the strawberries turn red. Apart from giving strawberries their red color, anthocyanins also act as antioxidants, and these compounds are the most abundant in strawberries. Anthocyanins in strawberries are derived from pelargonidin [24]. Anthocyanins are responsible for the red and blue colors in horticultural products [25]. Two anthocyanidin glycosides, pelargonidin 3-glucoside, and cyanidin 3-glucoside contribute mainly to the red color of strawberries [26]. During storage, the biosynthesis of anthocyanin compounds occurs continuously [27].

\section{Conclusion}

This study's conclusions, namely the value of color, texture, $\mathrm{pH}$, total acid content, total acid content, vitamin $\mathrm{C}$ content, and anthocyanin levels of strawberries at different maturity levels, showed significant differences $(\mathrm{P}<0.01)$. At the optimal maturity level, the $\mathrm{L} *$ value was 18.45 , a * was $67.04, \mathrm{~b} *$ was 20.86 , the texture was $7.46 \mathrm{~N}$, the $\mathrm{pH}$ was 3.36 , the total acid was 2.09 (meq $\mathrm{NaOH} / \mathrm{g}$ ), the total dissolved solids were $6.40{ }^{\circ} \mathrm{Brix}$, vitamin $\mathrm{C}$ levels were $66.24 \mathrm{mg} / 100$, and anthocyanin levels were $329.07 \mathrm{mg}$ PGN/100 g.

\section{Acknowledgments}

The author would like to thank all those who have helped in completing this research.

\section{References}

[1] Susianti, A., Riza Aristya, G., Sutikno, S., \& Sri Kasiamdari, R. (2015). Karakterisasi Morfologi dan Anatomi Stroberi (Fragaria x ananassa D. cv. Festival) Hasil Induksi Kolkisin. Biogenesis: Jurnal Ilmiah Biologi.3(2):66-75. 
[2] Giampieri, F., Forbes-Hernandez, T. Y., Gasparrini, M., Afrin, S., Cianciosi, D., Reboredo-Rodriguez, P., Varela-Lopez, A., Quiles, J. L., Mezzetti, B., \& Battino, M. (2017). The healthy effects of strawberry bioactive compounds on molecular pathways related to chronic diseases. Annals of the New York Academy of Sciences.1398(1):62-71.

[3] Mahmood, T., Anwar, F., Abbas, M., \& Saari, N. (2012). Effect of maturity on phenolics (Phenolic acids and flavonoids) profile of strawberry cultivars and mulberry species from Pakistan. International Journal of Molecular Sciences.13(4):4591-4607.

[4] Afrin, S., Gasparrini, M., Forbes-Hernandez, T. Y., Reboredo-Rodriguez, P., Mezzetti, B., Varela-López, A., Giampieri, F., \& Battino, M. (2016). Promising Health Benefits of the Strawberry: A Focus on Clinical Studies. Journal of Agricultural and Food Chemistry.64(22):4435-4449. https://doi.org/10.1021/acs.jafc.6b00857

[5] Schwab, W., \& Raab, T. (2006). Developmental Changes During Strawberry Fruit Ripening and PhysicoChemical Changes During Postharvest Storage. Production Practices and Quality Assessment of Food Crops.3(1):341-369. https://doi.org/10.1007/1-4020-2534-3_13

[6] Hanif, Z., \& Husna, H. (2014). Perbandingan Atribut Mutu Buah Stroberi yang Beredar di Pasar Tradisional dan Modern di Malang dan Yogyakarta Comparison of Quality Attributes of Strawberry Fruit at Traditional and Modern Market in Malang and Yogyakarta. Prosiding Seminar Nasional Perhorti : 469-476.

[7] Palapol, Y., S. Ketsa, D. Stevenson, J.M. Cooney, A.C. Allan, dan I.B. Ferguson.2009. Colour development and quality of mangosteen (Garcinia mangostana L.) fruit during ripening and after harvest. Postharvest Biology and Technology.51(3):349-353.

[8] AOAC. (2012). Official Methods of Analysis Association of Official and Analytical Chemists 17th Ed.

[9] Vuong, Q. V., Hirun, S., Chuen, T. L. K., Goldsmith, C. D., Bowyer, M. C., Chalmers, A. C., Phillips, P. A., \& Scarlett, C. J. (2014). Physicochemical composition, antioxidant and anti-proliferative capacity of a Lilly pilly (Syzygium paniculatum) extract. Journal of Herbal Medicine. 4(3):134-140.

[10] Nunes, M. C. N., J.K. Brecht, A.M.M.B. Morais dan S.A. Sargent. (2005). Possible influences of water loss and polyphenol oxidase activity on anthocyanin content and discoloration in fresh ripe strawberry (cv . Oso Grande ) During Storage at $1^{\circ} \mathrm{C}$. Sensory and Nutritive Qualities of Food.70(1):79-84

[11] Steel, R. G. D., \& Torrie, J. H. (1991). Principles and Procedures of Statistics. McGraw-Hill Book Company, New York, Toronto, London.

[12] Winarno, F. G. 1997. Kimia Pangan Dan Gizi. Gramedia Pustaka Utama. Jakarta

[13] Cahyono, B. 2008. Sukses Budidaya Stroberi di Pot dan Perkebunan. Yogyakarta: Lily

[14] Brummell, D. A., Cin, V. D., Lurie, S., Crisosto, C. H., \& Labavitch, J. M. (2004). Cell wall metabolism during the development of chilling injury in cold-stored peach fruit: Association of mealiness with arrested disassembly of cell wall pectins. Journal of Experimental Botany. 55(405):2041-2052.

[15] Al-juhaimi, F., Ghafoor, K., \& Babiker, E. E. (2012). Effect of gum arabic edible coating on weight loss, firmness, and sensory characteristics of cucumber (Cucumis sativus 1 .) Fruit during storage. Pak. J. Bot, 44(4), 1439-1444.

[16] Pujimulyani, D. 2009. Teknologi Pengolahan Sayur-Sayuran dan Buah-Buahan. Graha Ilmu. Yogyakarta.

[17] Nascimento, G.G.F., Locatelli, J.L., Freitas, P.C., and Silva, G.L. (2006). Antibacterial Activity Of Plant Extracts and PHytochemicals On Antibiotic-Resistant Bacteria. Brazilian J. Microbiol. 31:247-256

[18] Villanueva MJ, Tenorio MD, Esteban MA, Mendoza MC. 2004. Compositional changes during ripening of two cultivars of muskmelon fruits. Food Chem 87;179-185

[19] Ali, A., M. Maqbool, S. Ramachandran, dan P.G. Alderson. 2010. Postharvest biology and technology gum arabic as a novel edible coating for enhancing shelf-life and improving postharvest quality of tomato (Solanum lycopersicum L.) fruit. Postharvest Biology and Technology.58(1):42-47.

[20] Rachmayati, H, W.H. Susanto, J.M. Maligan.2017. Pengaruh Tingkat Kematangan Buah Belimbing (Averrhoa carambola L.) Dan Proporsi Penambahan Gula Terhadap Karakteristik Fisik, Kimia Dan Organoleptik Jelly Drink Mengandung Karaginan. Jurnal Pangan dan Agroindustri.5(1):49-60.

[21] Santoso BB. (2012). Fisiologi dan biokimia pada komoditi panenan hortikultura, Bahan Ajar, Fakultas Pertanian, Universitas Mataram, Mataram, Indonesia.

[22] Mudyantini, W., Anggarwulan, E., \& Rahayu, P. (2016). Penghambatan pemasakan buah srikaya (Annona squamosa L.) dengan suhu rendah dan pelapisan kitosan. Agric.27(1).

[23] Kartika, R.2010. Pengaruh Penambahan Caco3 Dan Waktu Penyimpanan Terhadap Kadar Vitamin C Pada Proses Penghambatan Pematangan Buah Tomat (Lycopersicum esculentum Mill). Jurnal Kimia Mulawarman. 8(1)

[24] Francesca, G. D. (2012). The Strawberry: Composition, Nutritional Quality, and Impact on Human Health. Elsevier, USA 
[25] Mullen, W., Mcginn, J., Lean, M.E.J., Maclean, M.R., Gardner, P., Duthie, G.G., Yokota, T. and Crozier, A. 2002. Ellagitannins, flavonoids, and other phenolics in red raspberries and their contribution to antioxidant capacity and vasorelaxation properties. Journal of Agricultural and Food Chemistry, 50(18): 5191-5196

[26] Ayala-Zavala, J. F., S.Y. Wang, C.Y. Wang dan G.A. González-Aguilar. (2004). Effect of storage temperatures on antioxidant capacity and aroma compounds in strawberry fruit.Food Science and Technology.37(7):687-695.

[27] Sogvar, O. B., Saba, M. K., \& Emamifar, A. (2016). Aloe vera and ascorbic acid coatings maintain postharvest quality and reduce the microbial load of strawberry fruit. Postharvest Biology and Technology, 114, 29-35. http://dx.doi.org/10.1016/j.postharvbio.2015.11.019. 